University of Nebraska - Lincoln

DigitalCommons@University of Nebraska - Lincoln

Faculty Papers and Publications in Animal

Science

Animal Science Department

January 1962

\title{
EVALUATION OF SIRES AVAILABLE THROUGH PLANNED MATING
}

L. Dale Van Vleck

University of Nebraska-Lincoln, dvan-vleck1@unl.edu

C. R. Henderson

Cornell University

H. W. Carter

Cornell University

Follow this and additional works at: https://digitalcommons.unl.edu/animalscifacpub

Part of the Animal Sciences Commons

Van Vleck, L. Dale; Henderson, C. R.; and Carter, H. W., "EVALUATION OF SIRES AVAILABLE THROUGH

PLANNED MATING" (1962). Faculty Papers and Publications in Animal Science. 318.

https://digitalcommons.unl.edu/animalscifacpub/318

This Article is brought to you for free and open access by the Animal Science Department at DigitalCommons@University of Nebraska - Lincoln. It has been accepted for inclusion in Faculty Papers and Publications in Animal Science by an authorized administrator of DigitalCommons@University of Nebraska - Lincoln. 
L. D. Van Vleck, C. R. Henderson and H. W. Carter. 1962. Evaluation of Sires Available through Planned Mating. Journal of Animal Science 21:30-32

Abstract: A comparison was made between records of daughters of three Holstein sires used in planned mating programs and records of their dams in order to determine the influence of selectivity of mating on sire evaluation. The number of daughter-dam sets ranged from 33 to 44 . The results showed that all three sires were mated to cows in above average herds. One sire was mated to cows which averaged above their herd mates by $599 \mathrm{lb}$. of milk and $31.6 \mathrm{lb}$. of fat. The other sires were mated to cows averaging nearer to their herd mates: $-285 \mathrm{lb}$. of milk and $-1.7 \mathrm{lb}$. of fat, and $334 \mathrm{lb}$. of milk, $0.5 \mathrm{lb}$. of fat respectively. Selection index estimates of daughter superiority were only slightly changed when dam records were considered in addition to daughter records even for the sire mated to cows averaging considerably above their herd mates.

Copyright ${ }^{\odot} 1962$ American Society of Animal Science. Used by permission. 


\title{
EVALUATION OF SIRES AVAILABLE THROUGH PLANNED MATING
}

\author{
L. D. VanVleck, C. R. Henderson, and H. W. Carter \\ Cornell University, Ithaca, New York
}

$\mathrm{T}$ HERE is some concern that methods of sire evaluation which utilize contemporary stablemate averages can be biased by differential genetic merit of the mates of these sires. A little reflection, however, indicates that even if the cows to which some sires are mated are more highly selected than the mates of other sires, this differential merit will not affect seriously the ranking of sires according to the evaluation of their progeny. Until the present, data have not been readily available with which to study the seriousness of this problem. The present study does not deal with the question generally, but attempts only to discover the effect of the estimated genetic merit of dams on the evaluation of three sires which were used in planned matings. The term "planned mating" as understood for this study refers to matings through artificial insemination to sires which are not normally available for service except by special request at additional cost and which are not owned by the distributing organization. The three sires whose matings are studied were from "popular" herds and were older bulls without an evaluation on the basis of their artificially sired progeny. Thus, a situation worse than would normally exist with respect to selected mates seems likely to exist.

\section{Data and Procedure}

The 305 day, 2x, M.E. records of artificially sired progeny of three Holstein sires available through planned mating service which were found in the New York Dairy Records Processing Laboratory and the records of the dams of these progeny were studied. Only the first record of each daughter appearing in the file was used. Most of these were actually first lactation records. Similarly only one record from each dam was selected. If possible, the selection was such that this record was made during about the same period of time as the daughter record. The number of records in each sire group is listed in table 1. Many of the progeny records did not have corresponding dam records in the file.

The daughter average for milk and fat for each sire was computed as well as the cor- responding average of adjusted stablemate averages, for all daughters in the file and for those daughters having dam records in the file. Similar averages were computed for the available dam records. These averages are also presented in table 1 . The adjusted stablemate average is essentially the average of the herd mates which started records in the same yearseason as the individual adjusted for the regression of true stablemate average on the stablemate average. This procedure was first described by Henderson et al. (1954), and was explained in more detail by Henderson (1956) and by Heidhues et al. (1960).

\section{Results and Discussion}

The mates for all three sires were evidently from above average herds as can be seen in table 1 . The current 5-year DHIA averages for New York Holsteins are 12,280 lb. of milk and $442 \mathrm{lb}$. of fat. Only one of the sires was mated to cows whose records were much above their corresponding stablemate averages. In fact, for fat production the mates of two sires were less than $2 \mathrm{lb}$. above or below their stablemate averages. The milk production of the mates of the same two sires was285 and $334 \mathrm{lb}$. different from their herd mates. The other sire, however, was mated to cows which were considerably above their herd mates in milk and fat production. It is necessary to examine the effect of this superiority on the evaluation of the sire.

Index procedures will be used to compare evaluation based on only daughter records and evaluation considering also the dam records. In order to correct for known environmental effects the records will be expressed as deviations from their adjusted stablemate averages which removes the effects of the herd, year and season of freshening.

The index when using only daughter records is $I_{0}=b\left(\bar{Y}_{0}-\bar{X}_{0}\right)$ where $I_{0}$ is the index, $b$ is the regression coefficient for the regression of the true daughter superiority on the daughter average, $\bar{Y}_{0}$ is the daughter average and $\vec{X}_{0}$ is the average of the corresponding adjusted stablemate averages. It is noted that this expresses the predicted superiority of a sire's 
TABLE 1. AVERAGES OF MILK AND FAT RECORDS OF DAUGHTERS AND MATES OF THREE PLANNED MATING SIRES AND THE AVERAGES OF THEIR STABLEMATE AVERAGES

\begin{tabular}{|c|c|c|c|c|c|c|c|c|}
\hline \multirow[b]{2}{*}{ Sire } & \multirow[b]{2}{*}{ Rec. } & \multirow[b]{2}{*}{ No. } & \multicolumn{3}{|c|}{ Milk, lb. } & \multicolumn{3}{|c|}{ Fat, lb. } \\
\hline & & & $\begin{array}{c}\text { Dau. or dam } \\
\text { Average }\end{array}$ & $\begin{array}{c}\text { Stablemate } \\
\text { Average }\end{array}$ & Difference & $\begin{array}{c}\text { Dau. or dam } \\
\text { Average }\end{array}$ & $\begin{array}{c}\text { Stablemate } \\
\text { Average }\end{array}$ & Difference \\
\hline Sover. Coch. & $\begin{array}{l}(1)^{a} \\
(2)^{b} \\
(3)^{c}\end{array}$ & $\begin{array}{l}91 \\
38 \\
38\end{array}$ & $\begin{array}{l}13,125 \\
13,752 \\
13,911\end{array}$ & $\begin{array}{l}13,302 \\
13,955 \\
14,196\end{array}$ & $\begin{array}{r}-177 \\
-203 \\
-285\end{array}$ & $\begin{array}{l}499.7 \\
528.1 \\
533.7\end{array}$ & $\begin{array}{l}488.1 \\
521.4 \\
535.4\end{array}$ & $\begin{array}{r}11.6 \\
6.7 \\
-1.7\end{array}$ \\
\hline Duke & $\begin{array}{l}(1) \\
(2) \\
(3)\end{array}$ & $\begin{array}{l}43 \\
33 \\
33\end{array}$ & $\begin{array}{l}16,154 \\
16,075 \\
14,430\end{array}$ & $\begin{array}{l}13,291 \\
13,415 \\
13,831\end{array}$ & $\begin{array}{r}2,863 \\
2,660 \\
599\end{array}$ & $\begin{array}{l}588.1 \\
584.7 \\
536.1\end{array}$ & $\begin{array}{l}493.1 \\
499.2 \\
504.5\end{array}$ & $\begin{array}{l}95.0 \\
85.5 \\
31.6\end{array}$ \\
\hline Aristocrat & $\begin{array}{l}(1) \\
(2) \\
(3)\end{array}$ & $\begin{array}{l}55 \\
44 \\
44\end{array}$ & $\begin{array}{l}14,075 \\
14,009 \\
13,986\end{array}$ & $\begin{array}{l}13,425 \\
13,377 \\
13,652\end{array}$ & $\begin{array}{l}650 \\
632 \\
334\end{array}$ & $\begin{array}{l}517.5 \\
518.7 \\
496.2\end{array}$ & $\begin{array}{l}485.5 \\
484.7 \\
495.7\end{array}$ & $\begin{array}{r}32.0 \\
34.0 \\
0.5\end{array}$ \\
\hline
\end{tabular}

a (1) Single records of all daughters in the file.

b (2) Single records of daughters also having dam records in the file.

c (3) Single records of dams.

daughters above their stablemates. The average for all sires is, of course, zero, so that the usual constant term, $\mu$, is omitted as is the constant term corresponding to the mean of deviations of daughter averages from their stablemate averages. The regression coefficient $\mathrm{b}$ is determined from the usual equation:

$\mathrm{V}\left(\overline{\mathbf{Y}}_{\mathrm{o}}-\overline{\mathbf{X}}_{0}\right) \mathrm{b}=\operatorname{COV}\left(\overline{\mathbf{Y}}_{0}-\overline{\mathbf{X}}_{\mathbf{o}}\right.$, true daughter superiority).

The variance of deviations from stablemate averages is $V\left(\bar{Y}_{0}-\bar{X}_{0}\right)=\sigma^{2}+\frac{\sigma^{2} \text { e }}{n}$ and the covariance between the average deviation and true daughter superiority, $\mathrm{T}$, is $\operatorname{COV}\left(\overline{\mathrm{Y}}_{0}-\overline{\mathrm{X}}_{0}\right.$, true daughter superiority) $=\sigma^{2}{ }_{s}$ where $\sigma^{2}{ }_{\mathrm{s}}$ is the between sire variance component, $\sigma^{2}$ is the within sire variance component of deviations from stablemate averages and $n$ is the number of records included in the average.

Thus, $\mathrm{I}_{0}=\frac{\mathrm{n}}{\mathrm{n}+\frac{\sigma_{\mathrm{e}}^{2}}{\sigma_{\mathrm{s}}^{2}}}\left(\overline{\mathrm{Y}}_{0}-\overline{\mathrm{X}}_{\mathrm{o}}\right)$.

When the deviations of dam records from their herd mates are also considered the index becomes:

$I_{1}=b_{1}\left(\bar{Y}_{0}-\bar{X}_{0}\right)+b_{2}\left(\bar{Y}_{d}-\bar{X}_{d}\right)$ where $\bar{Y}_{d}$ is the average of records of dams of the progeny and $\bar{X}_{d}$ is the corresponding average of stablemate averages. Hickman (1961) has proposed a similar procedure for evaluating dairy bulls from Canadian R.O.P. records.

The equations to solve for the b's are:

$\mathrm{V}\left(\overline{\mathbf{Y}}_{\mathrm{o}}-\overline{\mathbf{X}}_{0}\right) \mathrm{b}_{1}+\operatorname{COV}\left(\overline{\mathbf{Y}}_{\mathrm{o}}-\overline{\mathbf{X}}_{\mathbf{o}}, \overline{\mathbf{Y}_{\mathrm{d}}}-\overline{\mathbf{X}}_{\mathrm{d}}\right) \mathrm{b}_{2}$ $=\operatorname{COV}\left(\overline{\mathrm{Y}}_{0}-\overline{\mathrm{X}}_{0}, \mathrm{~T}\right)$

$\operatorname{Cov}\left(\overline{\mathrm{Y}}_{\mathrm{o}}-\overline{\mathrm{X}_{0}}, \overline{\mathrm{Y}_{\mathrm{d}}}-\overline{\mathrm{X}_{\mathrm{d}}}\right) \mathrm{b}_{1}+\mathrm{V}\left(\overline{\mathrm{Y}_{\mathrm{d}}}-\overline{\mathrm{X}_{\mathrm{d}}}\right) \mathrm{b}_{2}$ $\left.=\operatorname{COV} \overline{\left(Y_{d}\right.}-\overline{X_{d}}, T\right)$
Under the usual assumptions of no relationships between animals in the sets $\left(\overline{\mathrm{Y}}_{0}, \overline{\mathrm{X}}_{\mathrm{o}}\right)$, $\left(\overline{\mathrm{Y}}_{0}, \overline{\mathrm{X}}_{\mathrm{d}}\right),\left(\overline{\mathrm{X}}_{0}, \overline{\mathrm{Y}}_{\mathrm{d}}\right)$, and $\left(\overline{\mathrm{X}}_{\mathrm{o}}, \overline{\mathrm{X}}_{\mathrm{d}}\right)$, and of no relationship among animals in $\bar{Y}_{d}$, the equations can be rewritten as:

$$
\begin{aligned}
\left(\sigma_{\mathrm{s}}^{2}+\frac{\boldsymbol{\sigma}_{\mathrm{e}}^{2}}{\mathrm{n}}\right) \mathrm{b}_{1}+\frac{\operatorname{COV} \text { (daughter, dam) }}{\mathrm{n}} \mathrm{b}_{2}=\sigma_{\mathrm{s}}{ }^{2} \\
\frac{\operatorname{COV}(\text { daughter, dam })}{\mathrm{n}} \mathrm{b}_{1}+\frac{\sigma_{\mathrm{s}}+\sigma_{\mathrm{e}}^{2}}{\mathrm{n}} \mathrm{b}_{2}=\mathrm{O} .
\end{aligned}
$$

The further assumption that the ratio of additive genetic variance to the total variance, $\mathrm{h}$, is appropriate for describing both the covariance between daughters and dams and the covariance common to a half-sib progeny group allows the equations to be written in terms of $h$ as:

$$
\begin{gathered}
\frac{(n-1) h+4}{4}\left(b_{1}\right)+\frac{h}{2}\left(b_{2}\right)=\frac{n h}{4} \\
\frac{h}{2}\left(b_{1}\right)+b_{2}=0 .
\end{gathered}
$$

The solutions for $\left(b_{1}, b_{2}\right)$ are:

$$
\begin{aligned}
& \mathrm{b}_{1}=\frac{\mathrm{nh}}{(\mathrm{n}-1-\mathrm{h}) \mathrm{h}+4} \text { and } \\
& \mathrm{b}_{2}=-\frac{\mathrm{h}}{2} \mathrm{~b}_{1}=\frac{-\frac{\mathrm{n}}{2} \mathrm{~h}^{2}}{(\mathrm{n}-1-\mathrm{h}) \mathrm{h}+4} . \text { In terms }
\end{aligned}
$$
of $h$ the previous solution for $b$ becomes $b=\frac{n h}{(n-1) h+4}$ as is commonly given. A reasonable estimate of $h$ for milk and fat records made under New York conditions is 0.25 . The values of $b, b_{1}$, and $b_{2}$ then become

$$
b_{1}=\frac{n}{n+14.76} \text {, }
$$




$$
\begin{aligned}
& \mathrm{b}_{2}=-\frac{\mathrm{n}}{8 \mathrm{n}+118.08}, \text { and } \\
& \mathrm{b}=\frac{\mathrm{n}}{\mathrm{n}+15.00} .
\end{aligned}
$$

Table 2 presents the index estimates for the three sires (1) using the additional dam information, and (2) using only the daughter deviations for just those daughters with known dam records. The relatively small changes in estimated breeding values illustrate how little the dams affect the sire evaluation. Even the evaluation of "Duke" who was mated to cows averaging nearly $600 \mathrm{lb}$. of milk and $32 \mathrm{lb}$. of fat above their herd mates bias due to differences in the intensity with which the mates of various sires were selected is rarely large enough to need much correction in actual practice.

\section{Summary}

A comparison was made between records of daughters of three Holstein sires used in planned mating programs and records of their dams in order to determine the influence of selectivity of mating on sire evaluation. The number of daughter-dam sets ranged from 33 to 44 . The results showed that all three sires were mated to cows in above average herds.

\section{TABLE 2, SELECTION INDEX ESTIMATES OF DAUGHTER SUPERIORITY (1) USING DAUGHTER AND DAM DEVIATIONS FROM STABLEMATE AVERAGES, AND (2)

\begin{tabular}{|c|c|c|c|c|c|c|c|}
\hline \multirow[b]{3}{*}{ Sire } & \multicolumn{4}{|c|}{$\begin{array}{c}\text { Estimated daughter superiority using dam } \\
\text { and daughter deviations }\end{array}$} & \multicolumn{3}{|c|}{$\begin{array}{l}\text { Estimated daughter superiority } \\
\text { using only daughter deviations }\end{array}$} \\
\hline & $\overline{b_{1}}$ & $b_{2}$ & Milk & Fat & $\mathrm{b}$ & Milk & Fat \\
\hline & \multicolumn{2}{|c|}{ Weights } & \multicolumn{2}{|c|}{ Index estimate } & Weight & \multicolumn{2}{|c|}{ Index estimate } \\
\hline & & & $\mathrm{lb}$. & $\mathrm{lb}$. & & $\mathrm{lb}$. & $\mathrm{lb}$ \\
\hline Sover. Coch. & 0.7204 & -.0901 & -121 & 5.0 & 0.7170 & -146 & 4.8 \\
\hline Duke & 0.6915 & -.0864 & 1788 & 56.4 & 0.6875 & 1829 & 58.8 \\
\hline Aristocrat & 0.7486 & -.0936 & 442 & 25.4 & 0.7458 & 471 & 25.4 \\
\hline
\end{tabular} USING ONLY DAUGHTER DEVIATIONS FROM STABLEMATE AVERAGES}

is not changed much by consideration of this superiority. His estimated daughter superiority is reduced by only $41 \mathrm{lb}$. of milk and $2.4 \mathrm{lb}$. of fat. The other estimates are changed by smaller amounts.

\section{Conclusions}

One of the three planned-mating sires was mated to cows which averaged considerably above their herd mates. All were mated to cows in above average herds. The daughters were, as expected, also in high level herds. These results emphasize the importance of considering herd levels when evaluating sires and, especially, planned mating sires. Selection index estimates of daughter superiority were only slightly changed by considering the dam records, even for the sire mated to cows which averaged considerably above their herd mates. This indicates that selectivity of dams will not greatly influence sire evaluation. Theoretically, this can be easily seen since the estimate of daughter superiority will be raised or lowered by only about one-eighth of the dam's inferiority or superiority, respectively.

The results of this analysis are in agreement with Lush et al. (1941) who in a thorough discussion of the problem concluded that the
One sire was mated to cows which averaged above their herd mates by $599 \mathrm{lb}$. of milk and $31.6 \mathrm{lb}$. of fat. The other sires were mated to cows averaging nearer to their herd mates: $-285 \mathrm{lb}$. of milk and $-1.7 \mathrm{lb}$. of fat, and $334 \mathrm{lb}$. of milk, $0.5 \mathrm{lb}$. of fat respectively. Selection index estimates of daughter superiority were only slightly changed when dam records were considered in addition to daughter records even for the sire mated to cows averaging considerably above their herd mates.

\section{Literature Cited}

Heidhues, T., L. D. VanVleck and C. R. Henderson 1961. Actual and expected accuracy of sire proofs under New York system of sampling bulls. Z. Tierz. Zücht. Biol. $75: 323$.

Henderson, C. R. 1956. Cornell research on methods of selecting dairy sires. Proc. New Zealand Soc. An Prod. 16:69.

Henderson, C. R., H. W. Carter and J. T. Godfrey. 1954. Use of the contemporary herd average in appraising progeny tests of dairy bulls. J. Animal Sci. 13:949.

Hickman, C, G. 1961. Estimating breeding values of dairy bulls from Canadian R. O. P. records. Can. J. Animal Sci. (in press).

Lush, J. L., H. W. Norton III and Floyd Arnold. 1941. Effects which selection of dams may have on sire indexes. J. Dairy Sci. 24:695. 